\title{
Mniaecia jungermanniae and Puttea margaritella (lichenized Ascomycota) found in Poland
}

\author{
Paweł Czarnota*, Emil Hernik \\ Department of Agroecology, University of Rzeszów, Ćwiklińskiej 2, 35-601 Rzeszów, Poland
}

\section{Abstract}

Two hepaticolous fungi, Mniaecia jungermanniae and Puttea margaritella rarely recorded in Europe have recently been found in Polish Western Carpathians. Both species are also reported here for the first time from Poland. Notes on their taxonomy, ecology and distribution are provided.

Keywords: lichens, bryosymbionts, symbiosis, endophytes, liverworts, national park, Tatra Mts, Gorce range

\section{Introduction}

Many bryosymbiotic fungi have recently been studied towards their phylogenetic relationships to other Ascomycota to explain the adoption of highly specialized life strategies during evolution of fungi [1]. Some of the specialists are endophytic being confined only to the moos or liverwort hosts and others need additional symbioses with algal or cyanobacterial photobionts to form epibryophytic lichens. Such cases are not so rare and perhaps fungal endophytism is much more common than generally thought [2-4].

Two of the bryosymbiotic fungi, Mniaecia jungermanniae (Ascomycota, Leotiomycetes, Helotiales) and Puttea margaritella (Ascomycota, Lecanoromycetes) have been collected for the first time in Poland, while they are widespread in Europe and reported already from neighboring countries. Both are known to associate with liverworts, but the first species is regarded as a non-lichenized parasite [5-7] and the second is showed as lichenized despite it develops subcuticularly and does not form clearly structured thallus $[1,8]$.

\section{Material and methods}

Collections of Puttea margaritella were made in 2010 during lichenological investigations of deadwood lichens in Polish Tatra Mts by the first author, and findings of Mniaecia were made in

\footnotetext{
* Corresponding author. Email: pawczarnota@poczta.onet.pl Handling Editor: Beata Zagórska-Marek

This is an Open Access digital version of the article distributed under the terms of the Creative Commons Attribution 3.0 License (creativecommons.org/licenses/by/3.0/), which permits redistribution, commercial and non-commercial, provided that the article is properly cited.
}

2012 by both authors during their field trip in the Gorce Mts (Polish Western Beskidy Mts; Fig. 1).

All findings were morphologically and anatomically examined under microscopes. Hand-cut preparations mounted in water and $\mathrm{KOH}$ were studied to measure internal apothecial characters and to check their pigmentation and epihymenial crystals. Specimens have been deposited in the Herbarium of Gorce National Park (GPN). Nomenclature and synonyms of lichen-forming taxa follows Index Fungorum (http://indexfungorum.org).

Polish localities are mapped according to the Atpol grid square system [9] modified by Cieśliński and Fałtynowicz [10].

\section{Results and discussion}

\section{Mniaecia jungermanniae (Fr.) Boud.}

Hist. Class. Discom. Eur. (Paris): 99. 1907. 三Peziza jungermanniae Fr., Syst. mycol .(Lundae) 2(1): 144. 1822. $\equiv$ Ascobolus jungermanniae (Fr.) Berk. \& Broome, Ann. Mag. nat. Hist., Ser. 3. 15: 18 (No. 1082). 1865. Pseudopeziza jungermanniae (Fr.) Fuckel, Jb. nassau. Ver. Naturk. 23-24: 291. 1870. $\equiv$ Calloria jungermanniae (Fr.) Quél., Enchir. fung. (Paris): 324. 1886. $\equiv$ Humaria jungermanniae (Fr.) Sacc., Syll. fung. (Abellini) 8: 146. 1889.

DIAGNOSTIC CHARACTERS. This hepaticolous fungus was described and handmade illustrated in details several times $[5,6,11]$. Here it is photographed (Fig. 2a-d) and briefly described based on Polish findings.

External thallus absent. Apothecia blue to blue-green when moist, indistinctly marginate, $0.2-1.0 \mathrm{~mm}$ in diam. confined to leaves or steams of terricolous liverworts or sometimes growing directly on clayey soil between them. Hymenium up to 180 $\mu \mathrm{m}$ tall, colorless, except for the blue epihymenium, which is con-colored with distinct narrow excipulum. Hypothecium colorless. Asci 8-spored, cilindrical-clavate, numerous. Ascospores usually uniseriate, simple, elliptic with abundant lipidic 


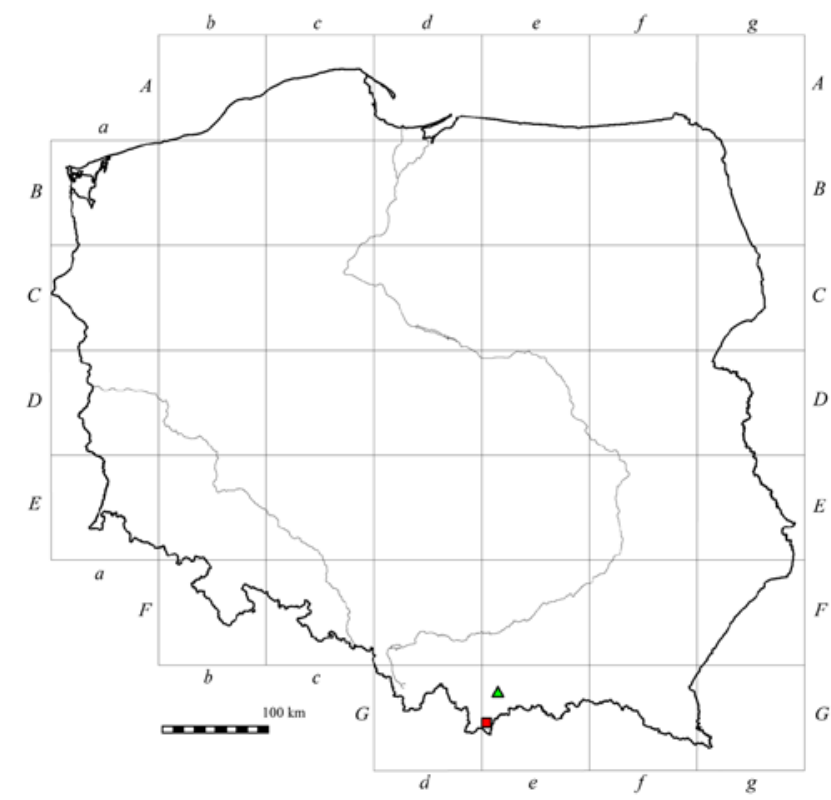

Fig. 1 Localities of Mniaecia jungermanniae (triangle) and Puttea margaritella (square) in Poland.

droplets, $8-12 \times 16-22 \mu \mathrm{m}$. Paraphyses usually simple with apices swollen to $6 \mu \mathrm{m}$ and bluish pigmented; some of them distinctly arise above hymenium.

NOTES. Regarding its blue apothecia spread over green small leafy liverworts, $M$. jungermanniae should be simply identified in the field, however, only in wet conditions. When it is dry, fruit-bodies are much smaller, almost black and usually unavailable to see. Raspe and De Sloover [5] provided the intraspecific hamathecial variability based on the description of $M$. jungermanniae by several researchers and their own investigations. The authors indicated two groups of examined specimens sometimes strongly differentiated in apothecial features, especially in the size of ascospores, asci and caps of paraphyses. Polish specimens correspond well with those described by Coppins and Chambers [12] and characterize by capitate long paraphyses which are distinctly higher than the hymenium (Fig. 2c).

Another representative of the genus, Mniaecia nivea ( $\mathrm{P}$. Crouan \& H. Crouan) Boud., found also in Central Europe, resembles $M$. jungermanniae except for the blue apothecial and mycellial pigment. Benkert and Otte [13] suggest even that $M$. nivea is possibly only an albino form of $M$. jungermanniae, but De Sloover [6] showed several differences in their anatomy to support the separation of both taxa. A distribution of $M$. nivea is less known in the contrary to M. jungermanniae, possibly due to its less visible apothecia in the field, which could be simply overlooked, especially when dry.

DISTRIBUTION AND ECOLOGY. Mniaecia jungermanniae was reported from several European countries: Iceland [14], Great Britain [12], Norway [15], Sweden [16], Belgium [5], the Netherlands [17], Luxembourg [18], France and Hungary [6], Germany (Saxony and Brandenburg) $[11,13]$ the Czech Republic [19], Austrian Styria [20-22], Julian Alps in Italia [23]. It has recently been found also in east North America (New Brunswick in Canada and E Pennsylvania in USA) [24]. Almost all of those collections were made in spring, when the apothecia of M. jungermanniae were developed. It suggests that it should be considered as a "spring fungus" available to see in the field in that time.
This endophytic fungus is known to be extremely confined to small liverworts belonging to the genera: Calypogeia, Cephalozia, Cephaloziella, Diplophyllum, Jungermannia, Lepidozia, Lophozia, Lophocolea and Nardia scalaris (Schrad.) Gray [6,13]. In Poland it was collected on terricolous members of Cephalozia and associated Jungermannia on the tourist path within the spruce montane forest.

SPECIMENS EXAMINED. Atpol Ge21, Poland, Carpathians, Western Beskidy Mts, Gorce Mts, Gorce National Park, by tourist track near the Borek pass, $49^{\circ} 33^{\prime} 32^{\prime \prime} \mathrm{N}, 20^{\circ} 08^{\prime} 43^{\prime \prime} \mathrm{E}$, alt. $1000 \mathrm{~m}$, on liverworts on clayey soil within spruce-fir mountain forest, 2012.05.04, leg. E. Hernik \& P. Czarnota 7408 (GPN); ibid., Turbacz nature reserve, by tourist track below Czoło Mt., $49^{\circ} 33^{\prime} 23^{\prime \prime} \mathrm{N}, 20^{\circ} 06^{\prime} 36^{\prime \prime} \mathrm{E}$, alt. $1100 \mathrm{~m}$, on liverworts on clayey soil within Carpathian beech-spruce-fir forest, 2012.05.05, leg. E. Hernik \& P. Czarnota 7407 (GPN).

\section{Puttea margaritella (Hulting) S. Stenroos \& Huhtinen}

In Stenroos, Huhtinen, Lesonen, Palice \& Printzen, Bryologist 112(3): 550. 2009. E Lecidea margaritella Hulting, Bot. Not. 1910: 304. 1910. EFellhanera margaritella (Huting) Hafellner, In: Hafellner \& Türk, Stapfia 76: 152. 2001.

= Lecidea symmictella var. albida Vain., Acta Soc. Fauna Fl. Fenn. 57(2): 416. 1934.

DIAGNOSTIC CHARACTERS. An excellent illustrated description of Puttea margaritella is presented by Stenroos et al. [8]. Here are included only some most distinguishable characters based on Polish materials (Fig. 2e-g).

Thallus almost invisible, hepaticolous. Apothecia small, up to $0.4 \mathrm{~mm}$ in diam., white to white cream, convex, immarginate, pruinose, usually constricted at the base. Apothecial section throughout colorless. Paraphyses frequently branched and anastomosed, septate, not capitate. Excipulum composed of paraphyse-like hyphae. External part of hamathecium and excipulum covered with thin layer of hyaline, small crystals dissolving in $\mathrm{KOH}$. Asci clavate, hemiamyloid in IKI (walls orange-brown). Ascospores simple, $(2.5-) 3 \times 6.5(-7) \mu \mathrm{m}$.

NOTES. Morphologically it characterizes by very small, white, immarginate apothecia appearing almost exclusively on the widespread liverwort Ptillidium pulcherrimum (Weber) Vain. Considering the apothecia, Puttea margaritella may resemble some morph of Micarea micrococca (Körb.) Gams ex Coppins distinguished by Czarnota and Guzow-Krzemińska [25] (Fig. 2a) as M. micrococca s.str. This species has also colorless apothecium, sometimes simple spores, branched, anastomosed paraphyses and moreover can grow as an epibryophyte. It differs, however, in the thallus structure; thallus superficial and composed of goniocysts while the thallus of $P$. margaritella is almost endophytic. Similar pale apothecia form also some species of Bacidina Vèzda [for example some morphs of B. chloroticula (Nyl.) Vězda \& Poelt, $B$. delicata (Larbal. ex Leight.) V. Wirth \& Vězda] as well as Fellhanera subtilis (Vězda) Diederich \& Sérus. and several members of the genus Vezdaea Tscherm.-Woess \& Poelt. Each of them is hyaline and almost colorless in the apothecial section, but among other differences their exciple are paraplectenchymatic or in the case of Vezdaea the excipulum is not developed. Ascospores in Bacidina spp. are acicular and multiseptate, in Fellhanera fusiform and also transversely septate, and in the case of Vezdaea if they are simple, are much larger. Despite the mentioned species can occasionally occupy bryophytes, all of them produce external, well developed thalli. Similar pale cream and whitish pruinose apothecia producing simple, small ascospores develops Biatora veteranorum Coppins \& Sérus., but 

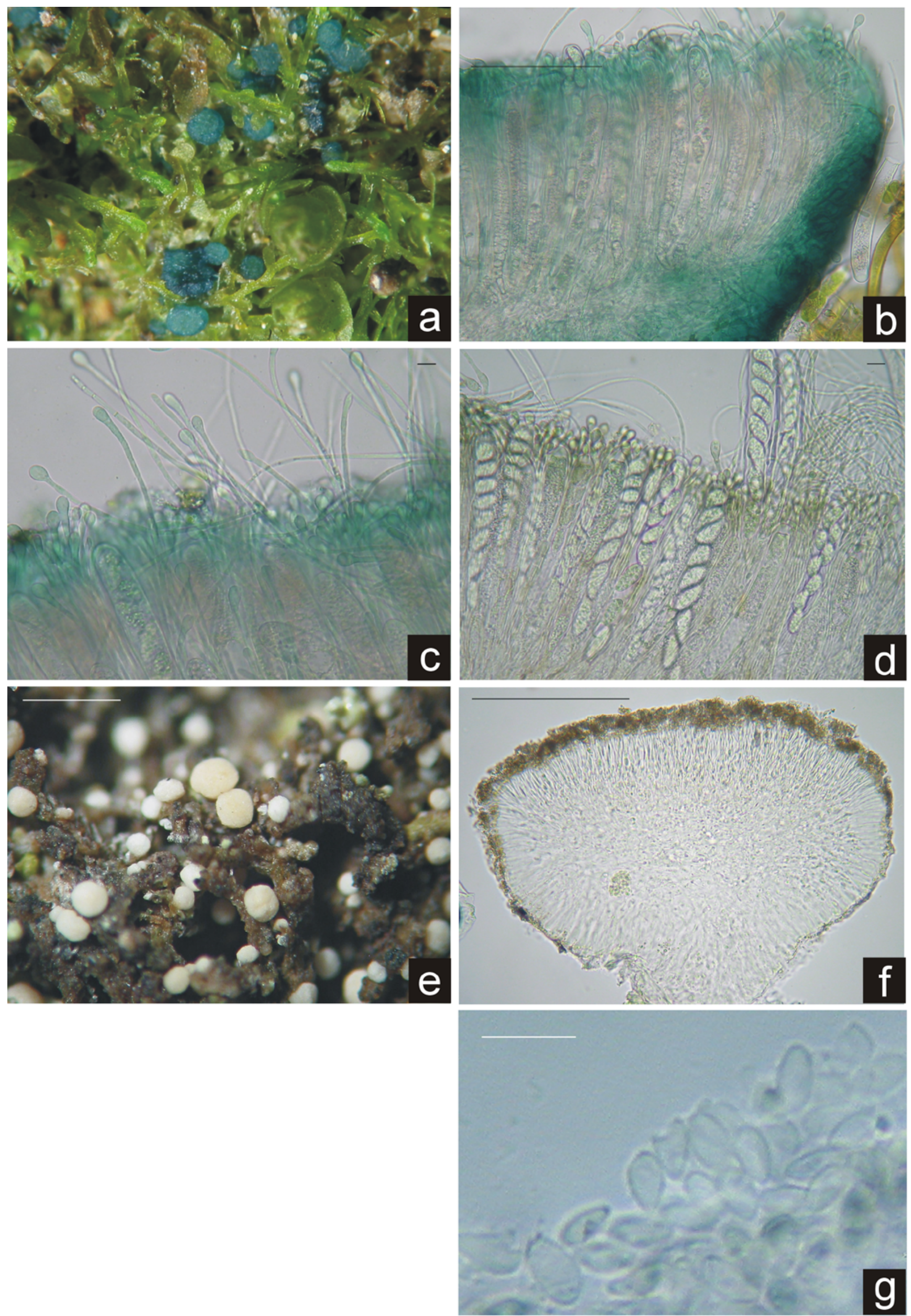

Fig. 2 Characters of Polish findings of Mniaecia jungermanniae (a-d) and Puttea margaritella (e-g). M. jungermanniae: habit (a); apothecial section (b); paraphyses (c); asci and ascospores (d); P. margaritella: habit (e); apothecial section (f); ascospores (g). Scale bars: b,f $100 \mu \mathrm{m}$; c,d,g $10 \mu \mathrm{m} ; \mathbf{e} 1 \mathrm{~mm}$. 
the species is exclusively lignicolous and its thallus despite is usually not superficial, is reach in stipitate, pruinose pycnidia [26], which have newer been observed in Puttea margaritella. Several next species showing closer phylogenetic affinities to $P$. margaritella have been also discussed by Sérusiaux et al. [26].

DISTRIBUTION AND ECOLOGY. So far Puttea margaritella is known mainly from Europe, from the whole Fennoscandia and Leningrad Region of Russia to the north (there the species seems to be not so rare) across the Czech Republic and Slovakia up to alpine regions of Austria and Switzerland to the south of the continent [8]. Recently it has also been recorded in Alaska [27]. Its closest localities to Poland are in Slovak Western Carpathians [8]. Here it is reported as new for the Tatra Mts and Poland.

In Poland P. margaritella was found only in the upper mountain spruce forests, in wet niches, surely because of the habitat requirements of its liverwort "host". Considering its inconspicuous habit, this lichenized fungus could be overlooked elsewhere, but on the other hand, its creamy white apothecia are strongly contrasting to their neighborhood, thus are quite simple to see. Its worldwide distribution suggests that $P$. margaritella is a mountain species in Central Europe and there should concentrate its next localities. At least in Polish mountains it seems to be however a rare lichen-forming fungus since intensive recent author's explorations of several Western Carpathian ranges resulted only in the two collections presented in this paper. Stenroos et al. [8] defined P. margaritella as a probably nectrotrophic parasite or a colonizer of already moribund, decaying parts of the liverwort host. Indeed, the Polish gatherings can confirm that opinion, but in this case except for the almost exclusively infected Ptillidium pulcherrimum [8], probably also dead Lophocolea heterophylla (Schrad.) Dum. is noted as its facultative host. Associated lichen-forming fungi in the Polish collections include: Cladonia sp., Hypogymnia physodes, Micarea botryoides and Vezdaea cf. retigera.

SPECIMENS EXAMINED. Atpol Ge-50, Poland, Carpathians, Tatra Mts, Tatra National Park: Dolina Rybiego Potoku valley, below Opalone Mt., forest section no. $53 \mathrm{f}, 49^{\circ} 13^{\prime} 10.5^{\prime \prime} \mathrm{N}$, $20^{\circ} 05^{\prime} 05.6^{\prime \prime} \mathrm{E}$, on dead liverwort Ptillidium pulcherrimum on bark of dead Picea abies within upper montane spruce forest Plagiothecio-Piceetum, alt. 1330 m, 2010.07.02, leg. Czarnota 6710 (GPN); ibid., Dolina Waksmundzka valley, forest section $66 \mathrm{a}, 49^{\circ} 15^{\prime} 03.4^{\prime \prime} \mathrm{N}, 20^{\circ} 04^{\prime} 58.8^{\prime \prime} \mathrm{E}$, on dead liverworts Ptillidium pulcherrimum and Lophocolea heterophylla on log of windthrowed Picea abies in upper montane spruce forest, alt. 1280 m, 2010.10.04, leg. P. Czarnota 7125 (GPN).

\section{Acknowledgements}

Special thank to Prof. Adam Stebel (Sosnowiec, Medical University of Silesia) for determination of liverworts infected by both presented fungi. This research was supported by the Polish Ministry of Science and Higher Education, grant No. N N305 306835 (P. Czarnota). A part of this study was financially supported by the University of Rzeszów task grant No. WBR/ KAiAK/DS/5/ 2012.

\section{Authors' contributions}

The following declarations about authors' contributions to the research have been made: field studies, determination, laboratory works, photographs, writing the manuscript: PC; field studies, bibliography studies: EH.

\section{References}

1. Stenroos S, Laukka T, Huhtinen S, Döbbeler P, Myllys L, Syrjänen K, et al. Multiple origins of symbioses between ascomycetes and bryophytes suggested by a five-gene phylogeny. Cladistics. 2009;26(3):281-300. http:// dx.doi.org/10.1111/j.1096-0031.2009.00284.x

2. Hyde KD, Soytong K. The fungal endophyte dilemma. Fungal Divers. 2008;33:163-173.

3. Rodriguez RJ, White JF, Arnold AE, Redman RS. Fungal endophytes: diversity and functional roles. New Phytol. 2009;182(2):314-330. http:// dx.doi.org/10.1111/j.1469-8137.2009.02773.x

4. Pressel S, Bidartondo MI, Ligrone R, Duckett JG. Fungal symbioses in bryophytes: new insights in the twenty first century. Phytotaxa. 2010;9:238-253.

5. Raspe O, De Sloover JR. Morphology, ecology and chorology of Mniaecia jungermanniae (Ascomycota) in Belgium and the significance of its association to leafy liverworts (Jungermanniales). Belg J Bot. 1998;131(2):251-259.

6. De Sloover JR. Présence en Belgique de Mniaecia nivea et M. jungermanniae (Ascomycota: Leotiales). Lejeunia. 2001;166:1-13.

7. Pressel S, Duckett JG. The parasitic ascomycete Mniaecia jungermanniae induces the formation of giant perichaetia and apogamous sporophytes in leafy liverworts. Can J Bot. 2006;84(3):384-392. http://dx.doi.org/10.1139/ b06-004

8. Stenroos S, Huhtinen S, Lesonen A, Palice Z, Printzen C. Puttea, gen. nov., erected for the enigmatic lichen Lecidea margaritella. Bryologist. 2009;112(3):544-557. http://dx.doi.org/10.1639/0007-2745-112.3.544

9. Zając A. Atlas of distribution of vascular plants in Poland (ATPOL). Taxon. 1978;27(5-6):481. http://dx.doi.org/10.2307/1219899

10. Cieśliński S, Fałtynowicz W. Note from editors. In: Cieśliński S, Fałtynowicz W, editors. Atlas of the geographical distribution of lichens in Poland. Cracow: W. Szafer Institute of Botany, Polish Academy of Sciences; 1993. p. 7-8.

11. Hardtke HJ. Zum vorkommen von Mniaecia jungermanniae (Nees ex Fr.) Boud. in Sachsen. Z Mykol. 1994;60(1):199-202.

12. Coppins BJ, Chambers SP. Mniaecia Boud. (1885). In: Smith CW, Aptroot A, Coppins BJ, Fletcher A, Gilbert OL, James PW, et al., editors. The lichens of Great Britain and Ireland. London: British Lichen Society; 2009. p. 611-612.

13. Benkert D, Otte V. Mniaecia jungermanniae und Podophacidium xanthomelum, zwei seltene Arten der Leotiales (Ascomycetes) in Brandenburg. Verh Bot Ver Berl Brandenbg. 2006;139:187-193.

14. Hallgrímsson H, Eyjólfsdóttir GG. Íslenskt sveppatal. I. Smásveppir. Fjölrit: Náttúrufræðistofnun Íslands; 2004. (Fjölrit Náttúrufræðistofnunar; vol 45).

15. Eckblad FE. Bidrag til Vestlandets soppflora. Blyttia. 1975;33:245-255.

16. Eriksson OE. The non-lichenized ascomycetes of Sweden. Umeå: Department of Ecology and Environmental Science, Umeå University; 2009.

17. Strijbosch H. Mniaecia jungermanniae (Nees apud Fr.) Boud., een ascomyceet op levende levermossen. Coolia. 1972;15:95-99.

18. Shultheis B, Tholl MT. Journées luxembourgeoises de mycologie vernale 2001. Bull Soc Nat Luxemb. 2003;104:21-39.

19. Lichen-forming and lichenicolous fungi in herbarium CBFS. Herbarium materials of Vondrak J. [Internet]. 2013 [cited 2013 Feb 26]; Available from: http://botanika.prf.jcu.cz/lichenology/data.php

20. Maurer W, Poelt J, Reidl J. Die Flora des Schöckl-Gebietes bei Graz (Steiermark, Österreich). Mitt Abt Bot Landesmus Joanneum Graz. 1983;11-12:1-104.

21. Hafellner J. Ein Beitrag zur Flechtenflora für die Naturräume Weststeirisches Hügelland, Sausal und Windische Bühel (Steiermark). Fritschiana. 2003;43:47-63.

22. Hafellner J. Zur Diversität lichenisierter und lichenicoler Pilze im Gebiet der Koralpe (Österreich: Kärnten und Steiermark, Slowenien). Mitt Naturwiss Vereines Steiermark. 2008;138:29-112. 
23. Tretiach M. Further additions to the Italian lichen flora. Cryptogam Mycol. 2004;25(2):173-183.

24. New York Botanical Garden. Mycology collections portal [Internet]. 2013 [cited 2013 Feb 26]; Available from: http://mycoportal.org/portal/taxa/ index.php?taxon=16158\&taxauthid $=1 \& \mathrm{cl}=$ North\%20America

25. Czarnota P, Guzow-Krzemińska B. A phylogenetic study of the Micarea prasina group shows that Micarea micrococca includes three distinct lineages. Lichenologist. 2009;42(1):7. http://dx.doi.org/10.1017/S0024282909990211
26. Sérusiaux E, Brand AM, Motiejunaite J, Orange A, Coppins BJ. Lecidea doliiformis belongs to Micarea, Catillaria alba to Biatora, and Biatora ligni-mollis occurs in Western Europe. Bryologist. 2010;113(2):333-344. http://dx.doi.org/10.1639/0007-2745-113.2.333

27. Spribille T, Pérez-Ortega S, Tønsberg T, Schirokauer D. Lichens and lichenicolous fungi of the Klondike Gold Rush National Historic Park, Alaska, in a global biodiversity context. Bryologist. 2010;113(3):439-515. http://dx.doi.org/10.1639/0007-2745-113.3.439 